\title{
It Was the Best of Times, It Was the Worst of Times...
}

In this double issue, MEDICC Review celebrates a cornucopia of achievements, but in an atmosphere of uncertainty about the future of US health care and about US-Cuba relations.

On the celebration front...Dr Tedros Adhanom Ghebreyesus (Ethiopia) became WHO's first African Director-General on July 3. In his address to WHO staff, Dr Tedros (as he prefers) emphasized that "universal health coverage....is a human rights issue. And the responsibility of national governments. It's not only a technical matter but even more so a political one. Countries should compare their results to their peers and learn from each other." This must sit painfully with many Americans, who are protesting in record numbers attempts by some in Congress to dismantle their health coverage and leave millions without care altogether. In this context, it is ironic that the Commonwealth Fund ranks the USA last among 11 wealthy countries in health system performance,[1] and health system efficiency ranks well below Cuba and some other poorer countries.[2]

On the brighter side of the health equity coin, in May WHO honored Cuba's Henry Reeve International Medical Contingent, the Dr Lee Jong-wook Memorial Prize for Public Health. MEDICC Review joins the global health community in lauding this well-deserved recognition. Formed in 2005 to offer disaster recovery assistance to New Orleans after Hurricane Katrina, its help was turned down by Washington. However, the Contingent went on to spend months in post-quake Pakistan the same year, and in 2010 sent almost 1400 health professionals to Haiti to buttress the team of Cuban doctors already serving there.

Many international graduates of Havana's Latin American Medical School (ELAM) have also volunteered in the Contingent, representing a continuum of solidarity: ELAM has trained over 35,000 physicians, mainly from low- and middle-income countries, asking in return for their full scholarship only a moral commitment to practice in shortage areas. Among the graduates are also over 100 from the United States, the clear majority of those already practicing, living up to the pledge they made to serve the underserved. Hats off to them, and to the entire ELAM Class of 2017, which graduated this month and included 25 new MDs from the USA. Best wishes are also in order for ELAM graduate Dr Karen Mayorga Quirós, who was appointed Costa Rica's Minister of Health in June. A surgeon with training in social medicine, prevention, health education and population health, she is certainly well prepared to face the challenges of her new position

While we celebrate these positive milestones, we recognize that these are uncertain times in both the USA and Cuba, although for different-if related-reasons. It is still unclear what, if any health care coverage Americans will be ensured, and Cubans are wondering how proposed changes to travel and other regulations under the US embargo will affect their collective and individual economic futures. The new administration in Washington has promised to cut off much travel by Americans to Cuba-already subject to a ban on tourist travel-and to roll back hopeful signs of a new day in US-Cuba relations signaled by Presidents Barack Obama and Raúl Castro. Our journal stands for the free flow of health and medical communications, relations and cooperation, as we understand that this is the only way that all people can benefit from advances in medicine and population health.
And now for our contents: among our Editors' Choice articles this issue, Senior Editor Gorry's feature shares insights into how Cuba addresses the complex issues of autism. An Original Research article by Machado-Zaldívar presents a phylogenetic analysis of HIV-1B in Cuba, meant to trace today's strains back to their "earliest common ancestor," an important contribution to knowledige about HIV's evolution in Cuba. Research from Chile by CastilloLaborde inquires into health inequalities there and their relation to public and private insurance models. In a Viewpoint, LuisGonzálvez offers a conceptualization of personal responsibility for health in the context of a universal system, sharply contrasting her definition with the "blame the victim" version often used to thrust the burden of health entirely onto individuals. A second Viewpoint by Orozco-Muñoz explores the need for more creative approaches to prevent postpartum obesity in Cuba-particularly timely, in light of the US Institute for Health Metrics and Evaluation's report noting that excess weight contributed to 4 million deaths globally in 2015.

We take this opportunity to comment on mounting concern in academic publishing that what was once a social function-the advancement of human knowledge based on the free flow of ideas and information among scholars-is increasingly a profitdriven industry like any other. By 2013, five corporations virtually controlled scientific publishing ( $70 \%$, compared to $20 \%$ of it in 1973). One response to this was the so-called "open access," model, so-called, because the openness in most cases is just to the reader; the costs are simply turned over to the researchers, introducing another source of inequity. Only those who can afford to pay can publish. In a recent call for academics to take back control of research journals, Professor Stephen Merton of Imperial College London wrote that corporate publishing profit margins exceeding $30 \%$ "stick in the craw, particularly since they depend to a large extent on labour that these large publishing companies don't pay for."

MEDICC Review has always provided two-way open access, charging neither authors nor readers for access to what we consider an important social good. Like many nonprofits, our publisher faces challenging times, but MEDICC Review will continue to defend a publishing model we believe is ethical and just. In this context, we hope our readers will consider donating to our efforts at www.medicc.org.

Finally, our warmest congratulations to Dr Pastor Castell-Florit, Director of Cuba's National School of Public Health, on his appointment as President of the National Council of Scientific Societies in Health. Dr Castell-Florit co-chairs MEDICC's Academic Council and is a member of MEDICC Review's Editorial Board. - M

\section{The Editors}

1. Schneider EC, Sarnak DO, Squires D, Shah A, Doty MM. Mirror, Mirror 2017: International Comparison Reflects Flaws and Opportunities for Better U.S. Health Care [Internet]. New York: Commonwealth Fund; 2017 Jul [cited 2017 Jul 15]. 30 p. Available from: http://www.commonwealthfund.org/inter actives/2017/july/mirror-mirror/

2. Du L, Lu W. U.S. Health Care System Ranks as one of the Least-Efficient. Bloomberg [Internet]. 2016 Sep 28 [cited 2017 Jul 15]; [about 5 screens]. Available from: https://www.bloomberg.com/news/articles/2016-09-29/u-s-health -care-system-ranks-as-one-of-the-least-efficient 